\title{
Seroprevalence of SARS-CoV-2 Infection in Portugal in May-July 2020: Results of the First National Serological Survey (ISNCOVID-19)
}

\author{
Seroprevalência da Infecção por SARS-CoV-2 em Portugal \\ em Maio-Julho de 2020: Resultados do Primeiro Inquérito \\ Serológico Nacional (ISNCOVID-19)
}

Irina KISLAYA ${ }^{1}$, Paulo GONÇALVES ${ }^{2}$, Marta BARRETO ${ }^{1}$, Rita de SOUSA ${ }^{2}$, Ana Cristina GARCIA ${ }^{1}$, Rita MATOS $^{2}$, Raquel GUIOMAR ${ }^{2}$, Ana Paula RODRIGUES ${ }^{1}$, on Behalf of ISNCOVID-19 Group

\section{ISNCOVID-19 Group:}

Verónica GÓMEZ1 ${ }^{1}$, Ausenda MACHADO ${ }^{1}$, Carlos MATIAS DIAS ${ }^{1}$, Baltazar NUNES ${ }^{1}$, Rita ROQUETTE ${ }^{1}$, Mafalda SOUSA-UVA ${ }^{1}$, Ana Rita TORRES ${ }^{1}$, Inês COSTA², Jorge MACHADO², Carla MANITA², Fátima MARTINS², João SANTOS ${ }^{2}$, Sofia SOEIRO², Raquel ROCHA ${ }^{2}$, Carla ROQUE ${ }^{2}$, Nuno VERDASCA${ }^{2}$, Maria Amélia FRADE ${ }^{3}$, Rita RIBEIRO ${ }^{4}$, Manuel CARVALHO ${ }^{5}$, Rui PINTO $^{6}$, Laura BRUM ${ }^{7}$, Marco MARQUES ${ }^{8}$, Luísa PONTE ${ }^{9}$, Jorge QUEIROZ ${ }^{10}$, Eunice Cláudia MORENO TRINDADE ${ }^{11}$, Eurico GASPAR ${ }^{12}$, Cátia Juliana MAGALHÃES DA SILVA ${ }^{13}$, Patrícia MAÇÃO ${ }^{14}$, Sofia REIS ${ }^{15}$, Fátima VALE ${ }^{16}$, Paula CORREIA ${ }^{17}$, Julieta FERNANDES ${ }^{18}$, Alexandra DIAS ${ }^{19}$, Elsa SANTOS ${ }^{20}$, Francisca MANOEL ${ }^{21}$, Joana VIEIRA DE MELO ${ }^{22}$, Maria João VIRTUOSO ${ }^{23}$, Maria PEREIRA ${ }^{23}$, Judite SACHICUMBI ${ }^{24}$, Paulo ÁVILA ${ }^{25}$, Pedro BRÁZIO ${ }^{26}$, José ALVES ${ }^{27}$

Acta Med Port 2021 Feb;34(2):87-94 - https://doi.org/10.20344/amp.15122

\section{ABSTRACT}

Introduction: The aim of this study was to estimate and describe the prevalence of severe acute respiratory syndrome coronavirus 2 (SARS-CoV-2) specific antibodies (immunoglobulin M and/or immunoglobulin G) in Portugal in May-July 2020.

Material and Methods: A cross-sectional seroepidemiological survey was developed after the peak of the first epidemic wave on a sample of 2301 Portuguese residents, aged 1 year or older. Survey sample was selected using a two-stage stratified non-probability sampling design (quota sampling). SARS-CoV-2 immunoglobulin M and immunoglobulin $\mathrm{G}$ antibodies were measured in serum samples by enzyme-linked immunosorbent assay. Seroprevalence estimates of immunoglobulin M and/or immunoglobulin $\mathrm{G}$ and $95 \%$ confidence intervals were stratified by sex, age group, health region and education.

Results: Overall, seroprevalence was 2.9\% (95\% confidence interval: $2.0 \%-4.2 \%)$. Higher prevalence rates were observed in male $(4.1 \%, 95 \%$ confidence interval: $2.6 \%-6.6 \%)$ and those with secondary education $(6.4 \%, 95 \%$ confidence interval: $3.2 \%-12.5 \%)$ Differences in seroprevalence by age group and region were not statistically significant.

Discussion: The estimated seroprevalence of SARS-CoV-2 was higher than the cumulative incidence reported by the National Surveillance System but far from necessary to reach herd immunity.

1. Departamento de Epidemiologia. Instituto Nacional de Saúde Doutor Ricardo Jorge. Lisboa. Portugal.

2. Departamento de Doenças Infeciosas. Instituto Nacional de Saúde Doutor Ricardo Jorge. Lisboa. Portugal.

3. Associação Nacional de Laboratórios Clínicos. Lisboa. Portugal.

4. Centro de Medicina Laboratorial. Grupo Germano de Sousa. Lisboa. Portugal.

5. Unilabs Portugal. Porto. Portugal.

6. Joaquim Chaves Saúde. Algés. Portugal.

7. Synlab Portugal. Lisboa. Portugal.

8. Affidea. Lisboa. Portugal.

9. Beatriz Godinho Saúde. Leiria. Portugal.

10. AQUALAB - Laboratório Clínico e de Saúde Pública, Lda. Albufeira. Portugal.

11. Serviço de Pediatria. Centro Hospitalar Universitário de São João. Porto. Portugal.

12. Serviço de Pediatria. Centro Hospitalar de Trás-Os-Montes e Alto Douro. Vila Real. Portugal.

13. Unidade Local de Saúde do Alto Minho. Hospital de Santa Luzia. Viana de Castelo. Portugal.

14. Hospital Pediátrico. Centro Hospitalar e Universitário de Coimbra. Coimbra. Portugal.

15. Serviço de Pediatria. Centro Hospitalar Tondela-Viseu. Viseu. Portugal.

16. Unidade Local de Saúde da Guarda. Hospital Sousa Martins. Guarda. Portugal.

17. Departamento de Pediatria. Hospital Professor Doutor Fernando Fonseca. Amadora. Portugal.

18. Serviço de Pediatria. Centro Hospitalar do Médio Tejo. Torres Novas. Portugal.

19. Serviço de Pediatria. Hospital de Dona Estefânia. Centro Hospitalar Universitário de Lisboa Central. Lisboa. Portugal.

20. Consulta de Pediatria. Unidade Local de Saúde do Litoral Alentejano. Santiago de Cacém. Portugal.

21. Serviço de Pediatria. Hospital do Espírito Santo de Évora. Évora. Portugal.

22. Unidade Local de Saúde de Baixo Alentejo. Hospital José Joaquim Fernandes. Beja. Portugal.

23. Departamento de Pediatria. Centro Hospitalar Universitário do Algarve. Faro. Portugal.

24. Hospital de Horta EPER. Horta. Portugal.

25. Serviço de Medicina Interna. Hospital de Santo Espírito da llha Terceira. Angra do Heroísmo. Portugal.

26. Serviço de Pediatria. Hospital do Divino Espírito Santo. Ponta Delgada. Portugal.

27. Serviço de Patologia Clínica. Hospital Dr. Nélio Mendonça. Funchal. Portugal.

$\square$ Autor correspondente: Irina Kislaya. irina.kislaya@insa.min-saude.pt

Recebido: 21 de outubro de 2020 - Aceite: 02 de dezembro de 2020 - Online issue published: 01 de fevereiro de 2021 Copyright $\odot$ Ordem dos Médicos 2021 
Conclusion: Our results support limited extent of infection by SARS-CoV-2 in the study population possibly due to early lockdown measures implemented in Portugal and support the need to continue monitoring of SARS-CoV-2 seroprevalence in order to increase our knowledge about the evolution of the epidemic and to estimate the proportion of the susceptible population over time.

Keywords: Antibodies, Viral; COVID-19; COVID-19 Testing; Immunoglobulin G; Immunoglobulin M; Portugal; SARS-CoV-2; Seroepidemiologic Studies

\section{RESUMO}

Introdução: Este estudo tem como objetivo estimar e descrever a prevalência dos anticorpos específicos (imunoglobulina M e/ou imunoglobulina G) contra o vírus da síndrome respiratória aguda grave do coronavírus 2 (SARS-CoV-2) em Portugal em maio-julho de 2020.

Material e Métodos: Após o pico da primeira onda epidémica foi realizado um estudo seroepidemiológico transversal numa amostra de 2301 pessoas residentes em Portugal, com idade igual ou superior a um ano. A amostra foi selecionada recorrendo um desenho amostral não probabilístico bietápico estratificado por quotas. Procedeu-se à deteção de anticorpos específicos contra SARS-CoV-2 (imunoglobulina M e imunoglobulina G) em amostras de soro por ensaio de imunoabsorção enzimática. As estimativas da seroprevalência (imunoglobulina $\mathrm{M}$ e/ou imunoglobulina $\mathrm{G}$ ) e os respetivos intervalos de confiança a 95\% foram estratificadas por sexo, grupo etário, região de saúde e escolaridade.

Resultados: A seroprevalência de anticorpos específicos imunoglobulina M e/ou imunoglobulina G foi de 2,9\% (intervalo de confiança a $95 \%$ : $2,0 \%-4,2 \%)$, tendo sido mais elevada em homens (4,1\%, intervalo de confiança a 95\%: $2,6 \%-6,6 \%)$ e nos indivíduos com ensino secundário (6,4\%, intervalo de confiança a $95 \%$ : 3,2\% - 12,5\%). Não foram identificadas diferenças estatisticamente significativas na entre os grupos etários estudados, nem entre regiões.

Discussão: A seroprevalência estimada foi superior à incidência cumulativa de infeção reportada pelo Sistema Nacional de Vigilância, embora longe dos valores necessários para atingir a imunidade de grupo.

Conclusão: Os resultados indicam uma extensão limitada da infeção por SARS-CoV-2, na população estudada compatível com uma implementação precoce das medidas de confinamento em Portugal e suporta a necessidade de monitorização a seroprevalência de SARS-CoV-2 para conhecer a evolução da epidemia e proporção da população suscetível ao longo do tempo.

Palavras-chave: Anticorpos Antivirais; COVID-19; Estudos Seroepidemiológicos; Imunoglobulina G; Imunoglobulina M; Portugal; SARS-Cov-2; Testagem COVID-19

\section{INTRODUCTION}

The first confirmed case of coronavirus disease 2019 (COVID-19) in Portugal was notified on the $2^{\text {nd }}$ March 2020. On the $18^{\text {th }}$ March 2020, a general lockdown was implemented across the country, along with several public health measures aimed at restricting the spread of the infection. By July $8^{\text {th }} 2020,45477$ cases of COVID-19 and 1644 associated deaths had been reported. ${ }^{1}$

Given the limited knowledge of the epidemiological and serological characteristics of the severe acute respiratory syndrome coronavirus 2 (SARS-CoV-2) and the primary focus of national surveillance systems on patients with severe disease, the World Health Organization (WHO) recommended that countries should perform seroepidemiological surveys to investigate the extent of SARS-CoV-2 infection as determined by seropositivity in the general population. ${ }^{2}$

A standardized protocol for population-based age-stratified seroepidemiological investigations for SARS-CoV-2 was proposed to better understand a spread of infection, including mild and subclinical cases that did not require medical care, and to allow comparability of results across countries. $^{2}$

In Portugal, the first national serological survey, ISNCOVID-19, was developed by the National Health Institute Doutor Ricardo Jorge in partnership with the National Association of Clinical Pathology Laboratories and a network of public hospitals, following WHO recommendations. ${ }^{2}$ This study aimed to estimate the seroprevalence of SARS-CoV-2 specific antibodies [immunoglobulin (Ig)M and/or IgG] stratified by sex, age group, health region, education level and to determine the fraction of asymptomatic infections in MayJuly 2020.

\section{MATERIAL AND METHODS Study settings}

A nationwide cross-sectional serological survey was developed after the peak of the first epidemic wave of COVID-19 in Portugal, while the restriction measures imposed during the national lockdown were starting to be lifted. The target population of the survey included residents in Portugal (mainland and Autonomous Regions) aged one year old (yo) and over. Participants were recruited among the visiting partner laboratories or public hospitals during the study period, for reasons unrelated to COVID-19 and with a medical prescription for a blood test that involved venipuncture. Those unable to give their informed consent and those with conditions that could interfere with immune response, such as chronic liver disease, cancer in previous five years, immunodeficiency, organ transplantation or transfusion in previous six months, were excluded.

\section{Sampling}

A two-stage non-probability sampling design (quota sampling) stratified by age group was used. In order to estimate an expected seroprevalence of $2.5 \%$ in the $0-19$ yo and of $5 \%$ in the 20 yo and over, with an absolute precision of $2 \%$ for $95 \%$ confidence interval and a design effect of 1.5 , the required sample size was determined to be 2072 individuals.

Sampling units, namely individuals, were allocated homogeneously by health region (North, Centre, Lisbon and Tagus Valley, Alentejo, Algarve, and the Autonomous Regions of Madeira and Azores) in order to obtain estimates with similar precision in all regions. In order to ensure survey geographical coverage in North, Centre, Lisbon and Tagus Valley, and Alentejo regions, sample was allocated 
proportionally according to the distribution of the resident population, by NUT III, while in Algarve, Autonomous Regions of Madeira and Azores by smaller geographical units, since each of these three regions consists of a single NUT III.

Within each NUT III or equivalent smaller geographical unit, municipalities were selected by simple random sampling. The number of municipalities to select in each NUT III was proportional to the geographical unit population size within each health region (more municipalities were selected in larger NUT III). The final number of municipalities selected was 101 . Within each randomly selected municipality, data collection points were chosen, by convenience, from a nationwide network of private and public pathology laboratories. At least one data collection point was selected in each regional unit (NUT III level or equivalent). The number of data collection points was determined taking into consideration logistical issues, such as the number of days for observation and capacity to recruit participants (17 - 22 individuals in each data collection point) after lockdown restrictions were lifted. The selected laboratories consisted of 96 clinical pathology laboratories and 18 public hospitals located in 101 randomly selected municipalities (Fig. 1). Survey participants were recruited according to pre-defined sex-age group quota distributed by health region (homogenously), by NUT III (proportional to population size), by selected municipality (homogeneously within NUT III or equivalent). All individuals visiting data collection points for reasons unrelated to COVID-19 were screened for eligibility and invited to participate, until the respective quotas were completed.

\section{Data collection}

Fieldwork took place between the $21^{\text {st }}$ May and the $8^{\text {th }}$ July, 2020. Data was collected through self-administrated survey questionnaire for sociodemographic, clinical and epidemiological information, including information concerning contact with a suspected or confirmed case of COVID-19 and presence of signs and symptoms compatible with SARS-CoV-2 infection since March 2020. Blood samples ( 3 - $5 \mathrm{~mL}$ for adults and 1 - $2 \mathrm{~mL}$ for children) were collected from each participant. All samples were transported to the National Health Institute Doutor Ricardo Jorge for serological laboratory analysis.

\section{Laboratory analysis}

Presence of IgM against SARS-CoV-2 in serum samples was determined using the Wantai SARS-CoV-2 enzymelinked immunosorbent assay (ELISA) on the Dynex DS2 processor. According to the manufacturer's information, assay sensitivity was $86.1 \%$ and specificity was $99.4 \%$.

IgG against SARS-CoV-2 was determined by ELISA using the EUROIMMUN anti-SARS-CoV-2 assay on a fully automated I-2P analyzer. According to the manufacturer's information, assay sensitivity was $94.4 \%$ from day 10 after onset of symptoms, while specificity was $99.6 \%$.

\section{Case definitions}

Seroprevalence was estimated as the proportion of individuals who had a positive result for IgM and/or lgG.

Participants were classified as: a) symptomatic if they presented anosmia and/or three or more of the following symptoms: fever, chills, asthenia, odynophagia, cough, dyspnea, headache, nausea/vomiting, diarrhea; b) paucisymptomatic if they presented at least one of the previous symptoms without anosmia; or c) asymptomatic. ${ }^{3}$

\section{Statistical analysis}

Counts and percentages were used to describe survey participants. Seroprevalence and respective 95\% confidence intervals (CI95) were estimated at national level and stratified by sex, age group (0 - 9, 10 - 19, 20 - 39, $40-59$ and 60+), health region, education level and previous contact with a confirmed or suspected COVID-19 case. The design-adjusted chi-square test was used to compare estimates among population subgroups. ${ }^{4}$ Estimates were weighted to match the Portuguese population distribution by health region, age group and sex in 2019. More details on the weighting methodology can be found elsewhere. ${ }^{5}$ In brief, to correct sample structure for design features (allocation by health region and age group), for each participant in age group $i$, sex $k$ and region $l$, sampling weight $\left(W_{i k l}\right)$ was computed as following:

$$
w_{i k l}=\frac{N_{i k l}}{n_{i k l}} \times \frac{n}{N}
$$

where $N$ stands for overall population size, $n$ for overall sample size, $n_{i c l}$ for sample size in age group $i$, sex $k$ and region $l$ and $N_{i k l}$ for population size in age group $i$, sex $k$ and region $l$.

The data was analyzed using Stata $15.1^{\circledR}$ software. $^{6}$ Cases with missing data were excluded from the analysis, and no imputations were performed. Significance level was set at $5 \%$.

A sensitivity analysis was performed adjusting overall seroprevalence for serological assays characteristics using Rogan-Gladen formula ${ }^{7}$ which relates observed seroprevalence $(\rho)$ with true population seroprevalence $(\pi)$ and assay sensitivity and specificity:

$$
\pi=\frac{\rho+\text { Specificity }-1}{\text { Sensitivity }+ \text { Specificity }-1}
$$

Due to the small sample sizes of the studies on the performance of the serologic assays used, we opted to perform adjustment using sensitivity $(96.0 \%$, Cl95: 90.6\% - 98.3\%) and specificity (98.7\%, Cl95: $97.2 \%$ - 99.4\%) estimates from a meta-analysis by Deeks et al. ${ }^{8}$ Monte Carlo simulations were used to propagate uncertainty around estimates.

\section{Ethical considerations}

ISNCOVID-19 received ethical approval from the Ethics Commission of the National Health Institute Doutor Ricardo Jorge. All study participants or their legal representatives provided written informed consent. 


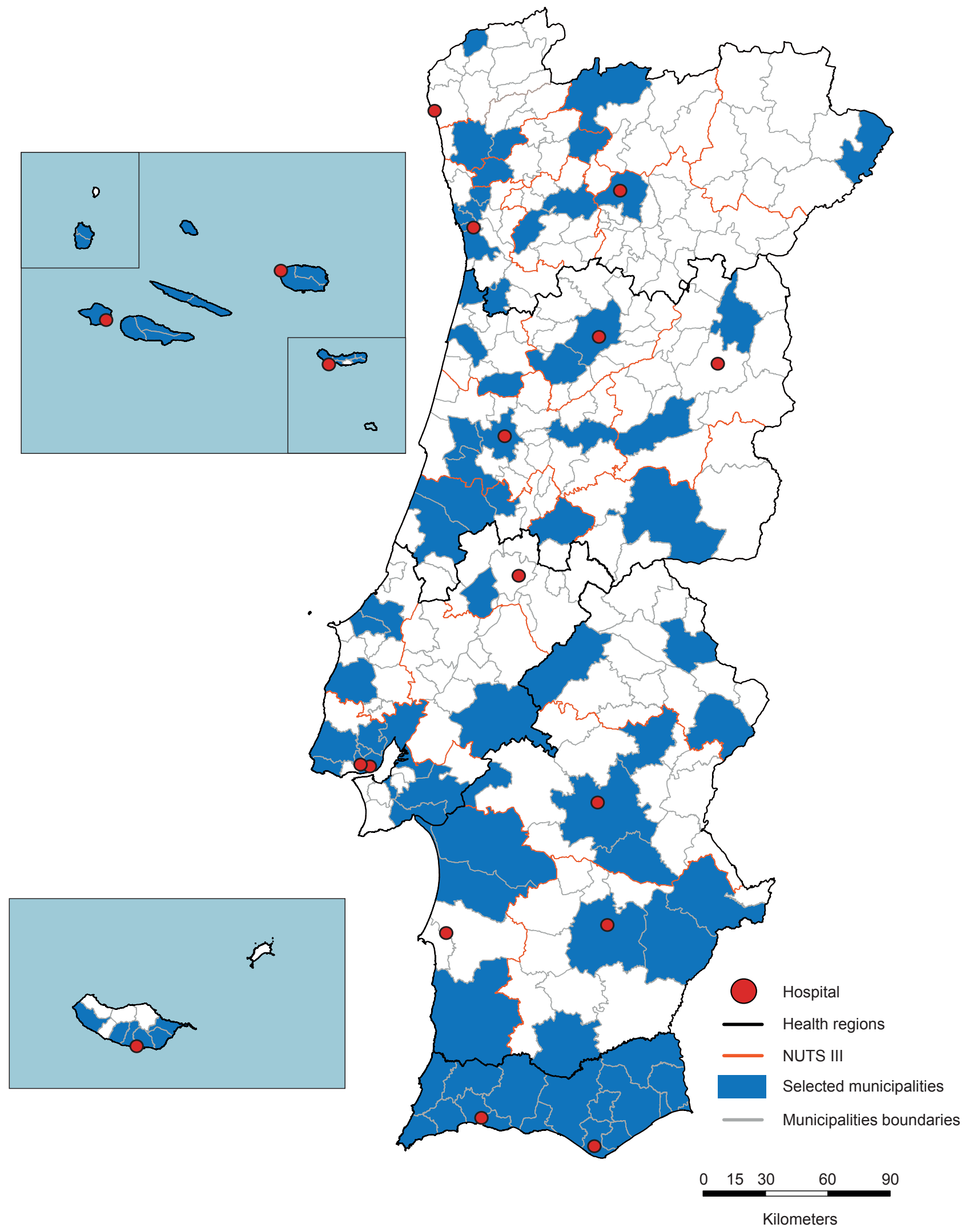

Figure 1 - Geographical distribution of data collection points in the ISNCOVID-19 


\section{RESULTS}

\section{Participant characteristics}

Participant characteristics are shown in Table 1. Overall, 2301 participants were recruited, 1467 through a network of clinical pathology laboratories and 834 through public hospitals. Of all participants, $52.8 \%$ were females. About $5.1 \%$ reported contact with a suspected or confirmed case of COVID-19 and $11.1 \%$ experienced symptoms compatible with SARS-CoV-2 infection. Of 2301 recruited participants, 12 reported previous positive tests for SARS-CoV-2.

\section{Seroprevalence}

From the 2301 participants, $30(1.9 \%$, Cl95: $1.1 \%$ $3.1 \%)$ were positive for IgM and 33 (1.9\%, Cl95: 1.2\% $3.1 \%$ ) for IgG against SARS-CoV-2 (Table 2). Overall, the seroprevalence of SARS-Cov-2 infection (positive for IgM and/or IgG) was $2.9 \%$ (Cl95: $2.0 \%-4.2 \%)$, significantly higher among males $(4.1 \%, \mathrm{Cl} 95: 2.6 \%-6.6 \%)$ compared to females $(1.8 \%$, Cl95: $0.9 \%-3.4 \%)(p=0.03)$.

No statistically significant differences in seroprevalence were observed by age group $(p=0.98)$ or region $(p=0.71)$. Seroprevalence varied by education level, and was higher among individuals with secondary school education $(6 \%, p$ $<0.01$ ).

Seroprevalence rates were higher among individuals who reported contact with a suspected or confirmed case of COVID-19 $(22.3 \%$ vs $2.0 \%, p<0.01)$ and in symptomatic individuals $(6.5 \%$ vs $2.0 \%)$. Among participants positive for IgM and/or IgG antibodies, 44.0\% (CI95: 26.9\% - 63.5\%) did not report any symptoms.

Table 1 - ISNCOVID-19 participants characteristics

\begin{tabular}{|c|c|c|}
\hline Characteristic & $\mathbf{n}$ & $\begin{array}{c}\% \\
\text { (Weighted) }\end{array}$ \\
\hline \multicolumn{3}{|l|}{ Sex, $(n=2301)$} \\
\hline Male & 1057 & 47.2 \\
\hline Female & 1244 & 52.8 \\
\hline \multicolumn{3}{|l|}{ Age group, $(n=2301)$} \\
\hline $1-9$ yo & 404 & 7.9 \\
\hline $10-19$ yo & 377 & 10.3 \\
\hline $20-39$ yo & 377 & 23.1 \\
\hline $40-59$ yo & 479 & 29.8 \\
\hline$\geq 60$ yo & 664 & 29.0 \\
\hline \multicolumn{3}{|l|}{ Health region, $(n=2301)$} \\
\hline North & 327 & 34.8 \\
\hline Centre & 335 & 16.0 \\
\hline Lisbon and Tagus Valley & 343 & 35.6 \\
\hline Alentejo & 266 & 4.5 \\
\hline Algarve & 351 & 4.3 \\
\hline Madeira & 329 & 2.5 \\
\hline Azores & 350 & 2.4 \\
\hline \multicolumn{3}{|l|}{ Education level*, $(n=1512)$} \\
\hline Cannot read or write / Elementary school & 426 & 21.1 \\
\hline Middle school & 352 & 22.6 \\
\hline Secondary school & 340 & 23.5 \\
\hline Higher education & 394 & 32.9 \\
\hline \multicolumn{3}{|c|}{ Previous contact with suspected or confirmed COVID-19 case, $(n=2294)$} \\
\hline No & 1909 & 75.9 \\
\hline Yes & 81 & 5.1 \\
\hline Unknown & 304 & 19.1 \\
\hline \multicolumn{3}{|l|}{ Self-reported symptoms ${ }^{* *},(n=2231)$} \\
\hline Asymptomatic & 1428 & 64.2 \\
\hline Paucisymptomatic & 557 & 24.6 \\
\hline Symptomatic & 246 & 11.1 \\
\hline
\end{tabular}

* only for participants aged 20 yo or above

** definition proposed by Póllan et al 
Table 2 - Anti-SARS-CoV-2 IgM, IgG seroprevalence in Portugal, May - July 2020

\begin{tabular}{|c|c|c|c|c|c|c|}
\hline & \multicolumn{2}{|l|}{$\lg M$} & \multicolumn{2}{|l|}{$\lg G$} & \multicolumn{2}{|c|}{$\lg M$ and/or IgG } \\
\hline & $\% *(95 \% \mathrm{Cl})$ & $p$ & $\% *(95 \% \mathrm{Cl})$ & $p$ & $\% *(95 \% \mathrm{Cl})$ & $p$ \\
\hline Overall sample & $1.9(1.1-3.1)$ & & $1.9(1.2-3.1)$ & & $2.9(2.0-4.2)$ & \\
\hline Sex & & 0.09 & & 0.10 & & 0.03 \\
\hline Male & $2.7(1.5-5.0)$ & & $2.8(1.5-4.9)$ & & $4.1(2.6-6.6)$ & \\
\hline Female & $1.1(0.4-2.7)$ & & $1.2(0.5-2.7)$ & & $1.8(0.9-3.4)$ & \\
\hline Age group & & 0.20 & & 0.61 & & 0.98 \\
\hline $1-9$ yo & $1.6(0.5-5.1)$ & & $2.1(0.8-5.4)$ & & $2.9(1.3-6.2)$ & \\
\hline $10-19$ yo & $0.6(0.1-3.6)$ & & $2.1(0.8-5.5)$ & & $2.2(0.8-5.5)$ & \\
\hline $20-39$ yo & $2.2(0.8-5.9)$ & & $0.7(0.1-4.8)$ & & $2.9(1.2-7.0)$ & \\
\hline $40-59$ yо & $3.1(1.4-6.7)$ & & $2.4(0.9-5.9)$ & & $3.2(1.5-6.7)$ & \\
\hline$\geq 60$ yo & $0.9(0.3-2.5)$ & & $2.4(1.1-4.9)$ & & $2.9(1.5-5.3)$ & \\
\hline Health region & & 0.84 & & 0.27 & & 0.71 \\
\hline North & $2.1(0.8-5.4)$ & & $2.1(0.9-5.0)$ & & $2.8(1.3-6.0)$ & \\
\hline Centre & $2.2(1.0-5.0)$ & & $0.9(0.3-3.1)$ & & $2.7(1.3-5.5)$ & \\
\hline Lisbon and Tagus Valley & $1.6(0.6-4.1)$ & & $2.7(1.4-5.2)$ & & $3.5(1.9-6.3)$ & \\
\hline Alentejo & $1.0(0.2-4.1)$ & & $0.8(0.2-3.9)$ & & $1.2(0.3-4.0)$ & \\
\hline Algarve & $2.1(0.9-4.9)$ & & $0.1(0.0-1.0)$ & & $2.2(1.0-5.0)$ & \\
\hline Madeira & $1.0(0.3-2.9)$ & & $0.6(0.1-2.9)$ & & $1.6(0.6-3.9)$ & \\
\hline Azores & $0.7(0.1-3.1)$ & & $2.4(1.1-5.0)$ & & $2.6(1.3-5.2)$ & \\
\hline Education level & & 0.01 & & $<0.01$ & & 0.01 \\
\hline $\begin{array}{l}\text { Cannot read or write / } \\
\text { Elementary school }\end{array}$ & $1.5(0.4-5.4)$ & & $1.5(0.5-4.6)$ & & $3.0(1.3-7.0)$ & \\
\hline Middle school & $1.5(0.5-4.5)$ & & $0.7(0.2-2.3)$ & & $1.7(0.6-4.5)$ & \\
\hline Secondary school & $5.0(2.2-10.9)$ & & $5.0(2.2-10.7)$ & & $6.4(3.2-12.5)$ & \\
\hline Higher education & $0.7(0.2-2.0)$ & & $0.8(0.2-2.9)$ & & $1.4(0.6-3.4)$ & \\
\hline $\begin{array}{l}\text { Previous contact with suspected or } \\
\text { confirmed COVID-19 case }\end{array}$ & & $<0.01$ & & $<0.01$ & & $<0.01$ \\
\hline No & $1.2(0.6-2.4)$ & & $0.9(0.5-1.7)$ & & $2.0(1.2-3.3)$ & \\
\hline Yes & $16.3(7.3-32.3)$ & & $20.5(10.2-36.9)$ & & $22.3(11.7-38.5)$ & \\
\hline Unknown & $0.7(0.2-3.5)$ & & $1.1(0.3-4.3)$ & & $1.3(0.4-4.2)$ & \\
\hline Self-reported symptoms ${ }^{* *}$ & & $<0.01$ & & $<0.01$ & & 0.06 \\
\hline Asymptomatic & $0.8(0.4-1.8)$ & & $1.5(0.8-2.8)$ & & $2.0(1.2-3.4)$ & \\
\hline Paucisymptomatic & $2.8(1.2-6.4)$ & & $1.2(0.5-2.9)$ & & $3.7(1.8-7.2)$ & \\
\hline Symptomatic & $6.3(2.4-15.3)$ & & $6.3(2.5-15.3)$ & & $6.5(2.6-15.3)$ & \\
\hline
\end{tabular}

* weighted proportion

** definition proposed by Póllan et al

\section{Sensitivity analysis}

Statistical adjustment for the assay characteristics resulted in an overall seroprevalence of 1.7\% (CI95: $0.0 \%-$ $3.3 \%)$.

\section{DISCUSSION}

The seroprevalence of specific IgM and/or IgG against SARS-CoV-2 estimated by the ISNCOVID-19 (2.9\%) was similar to that reported for the Spanish provinces bordering Portugal $^{3}$ and compatible with a limited extent of this infection in the Portuguese population between March and July 2020. However, this estimate is far from values required to reach herd immunity $(43 \%-67 \%))^{9,10}$
The estimated SARS-CoV-2 seroprevalence was higher than the attack rate reported by the national surveillance system (0.44 per 100 inhabitants), ${ }^{1}$ which is consistent with the evidence of lower capacity of surveillance systems to capture mild or asymptomatic cases., ${ }^{3,11-13}$

About $44 \%$ of seropositive participants did not report any symptom, indicating that they may have been asymptomatic or had overlooked mild symptoms during the acute phase of the infection. However, the possibility of recall bias regarding the occurrence of symptoms cannot be excluded.

The higher seroprevalence observed among male and among those with secondary education requires further investigation as literature is not consensual regarding 
gender differential risk of infection, and most studies report no differences. ${ }^{3,14-16}$ Our results regarding gender and education level may reflect differences in occupational exposure during the lockdown as during this period certain economic activities continued.

The differences in seroprevalence observed by health region were of reduced magnitude and not statistically significant. Since the survey sample size was calculated according to its main objective of estimating a seroprevalence but not to compare groups, this result may reflect lack of power to detect the differences of a small magnitude with negligible public health importance.

Among limitations that could have affected the study results, we should mention the lack of a representative sample of the Portuguese general population because research has shown that SARS-CoV-2 seroprevalence surveys may be seriously affected by self-selection or volunteer bias ${ }^{17}$ as individuals with previous diagnosis of COVID-19 volunteered more frequently to participate. ${ }^{17}$ In order to reduce this self-selection bias in the ISNCOVID-19 survey participants were recruited among those who already were in a laboratory with the objective to perform routine blood tests prescribed by a physician for reasons unrelated to COVID-19. This methodological option, on the other hand, may have resulted in sampling of individuals with higher proportion of chronic conditions than in general population, ${ }^{18}$ particularly among children, and this could have contributed to a lower seroprevalence resulting from a higher awareness and adoption of protection measures by these high-risk groups. Moreover, selecting participants among users of clinical pathology laboratories may have resulted in bias due to the documented educational gradient in access to diagnostic tests. ${ }^{18}$ However, the Portuguese Serological Survey for Vaccine Preventable Disease developed in 2015 - 2016, using similar sampling strategy among clinical pathology laboratories and public hospital users, did not demonstrate bias in the educational distribution of participants. ${ }^{5}$ Exclusion of institutionalized individuals from the present survey may have contributed to underestimation of SARS-CoV-2 seroprevalence since, according to the national surveillance system, several institutional facilities

\section{REFERENCES}

1. Direção-Geral da Saúde. Novo Coronavírus (COVID-19) Relatório de Situação n¹28. Lisboa: DGS; 2020.

2. World Health Organization. Seroepidemiological investigation protocol for coronavirus 2019 (COVID-19) infection [Internet]. 2020 [consulted 2020 Nov 10]. Available from: https://www.who.int/publications/i/item/ WHO-2019-nCoV-Seroepidemiology-2020.2.

3. Pollán M, Pérez-Gómez B, Pastor-Barriuso R, Oteo J, Hernán MA, Pérez-Olmeda $M$, et al. Prevalence of SARS-CoV-2 in Spain (ENECOVID): a nationwide, population-based seroepidemiological study. Lancet. 2020;396:535-44.

4. Rao J, Scott A. On simple adjustments to chi-square tests with sample survey data. Ann Stat. 1987;15:385-97.

5. Instituto Nacional de Saúde Dr. Ricardo Jorge. Inquérito Serológico Nacional 2015-2016: Doenças Evitáveis por Vacinação. Lisboa: INSA; 2015.

6. StataCorp. Stata Statistical Software: Release 15. College Station: StataCorp LP; 2017. for the elderly were affected by COVID-19 during the first wave. Despite possible bias, the adopted methodology allowed easy and rapid survey planning and implementation resulting in rapid data collection, analysis, and communication of updated information for public health decision.

\section{CONCLUSION}

In May-July 2020 the observed prevalence of anti-SARSCoV-2 specific antibodies was low in a survey population (2.9\%, CI95: $2.0 \%-4.2 \%)$ and comparable to other studies developed in similar settings with low incidence rates of COVID-19. Given the low sensitivity of the National Surveillance System to detect asymptomatic cases we emphasize the need of monitoring the distribution of specific antibodies against SARS-CoV-2 during the forthcoming months, especially after the second pandemic wave, in order to estimate the fraction of SARS-CoV-2 susceptible population and to inform vaccination strategy.

\section{ACKNOWLEDGMENTS}

We are grateful for all health professionals involved in ISNCOVID-19 data collection and all survey participants.

\section{PROTECTION OF HUMANS AND ANIMALS}

The authors declare that the procedures were followed according to the regulations established by the Clinical Research and Ethics Committee and to the 2013 Helsinki Declaration of the World Medical Association.

\section{DATA CONFIDENTIALITY}

The authors declare having followed the protocols in use at their working center regarding patients' data publication.

\section{COMPETING INTERESTS}

The authors have declared that no competing interests exist.

\section{FUNDING SOURCES}

The ISNCOVID-19 project team members did not receive any external funding.

7. Rogan WJ, Gladen B. Estimating prevalence from the results of a screening test. Am J Epidemiol. 1978;107:71-6.

8. Deeks J, Dinnes J, Takwoingi Y, Davenport C, Spijker R, Taylor-Phillips $S$, et al. Antibody tests for identification of current and past infection with SARS-CoV-2. Cochrane Database Syst Rev. 2020;6:CD013652.

9. Britton T, Ball F, Trapman P. A mathematical model reveals the influence of population heterogeneity on herd immunity to SARS-CoV-2. Science. 2020;369:846-9.

10. Papachristodoulou E, Kakoullis L, Parperis K, Panos G. Long-term and herd immunity against SARS-CoV-2: implications from current and past knowledge. Pathog Dis. 2020;78:ftaa025

11. Rosenberg E, Tesoriero J, Rosenthal E, Chung R, Barranco M, Styer L, et al. Cumulative incidence and diagnosis of SARS-CoV-2 infection in New York. Ann Epidemiol. 2020;48:23-9.e4.

12. Havers F, Reed C, Lim T, Montgomery J, Klena J, Hall A, et al. Seroprevalence of antibodies to SARS-CoV-2 in six sites in the United States, March 23-May 3,2020. JAMA Intern Med. 2020 (in press) doi: 
10.1001/jamainternmed.2020.4130

13. Wiersinga W, Rhodes A, Cheng A, Peacock S, Prescott H. Pathophysiology, transmission, diagnosis, and treatment of coronavirus disease 2019 (COVID-19): a review. JAMA. 2020;324:782-93.

14. Erikstrup C, Hother C, Pedersen O, Mølbak K, Skov R, Holm D, et al. Estimation of SARS-CoV-2 infection fatality rate by real-time antibody screening of blood donors. Clin Infect Dis. 2020 (in press). doi: 10.1093/ $\mathrm{cid} / \mathrm{ciaa} 849$.

15. Stringhini S, Wisniak A, Piumatti G, Azman A, Lauer S, Baysson $\mathrm{H}$, et al. Seroprevalence of anti-SARS-CoV-2 IgG antibodies in Geneva, Switzerland (SEROCoV-POP): a population-based study. Lancet. 2020;396:313-9.
16. Fischer B, Knabbe C, Vollmer T. SARS-CoV-2 IgG seroprevalence in blood donors located in three different federal states, Germany, March to June 2020. Euro Surveillance. 2020;25:2001285.

17. Ahmad Aziz N, Corman V, Echterhoff A, Richter A, Schmandke A, Schmidt ML, et al. Seroprevalence and correlates of SARS-CoV-2 neutralizing antibodies: Results from a population-based study in Bonn, Germany. medRxiv. 2020. doi: 10.1101/2020.08.24.20181206.

18. Barbadoro P, D'alleva A, Galmozzi S, Zocco G, Stanislao F Di, Prospero $\mathrm{E}$, et al. Variations in diagnostic testing utilization in Italy: Secondary analysis of a national survey. 2018 [consulted 2020 Nov 5]. Available from: https://doi.org/10.1371/journal.pone.0196673. 